\title{
SOCIAL INCLUSION OF BRAZILIAN PEOPLE WITH DISABILITIES THROUGH THE LENS OF CRITICAL THEORY OF TECHNOLOGY
}

\author{
Patricia da Silva Leite and Leonelo Dell Anhol Almeida \\ Postgraduate Program in Technology and Society (PPGTE) \\ Research Group Xuê: Participation, Interaction and Computing \\ Federal University of Technology - Paraná (UTFPR) - Brazil
}

\begin{abstract}
Technology is one of the sources of power more relevant in modern society. For that reason, technology is a social battlefield and a resource under power disputes. Technology is created and adapted to reproduce and incorporate society values as social groups who control technology creation. Thus, none technology is neutral or detached of a context. Instead, technology is an instrument used to change our society, at the same time that is reassembled by us. Considering that, critical theorist Andrew Feenberg elaborated the "Critical Theory of Technology" which discusses issues about technology in our society and the relationship between these two interrelated entities. Based on that, this paper critically analyzes the relationship of people with disabilities movements and technology and society changes, particularly with examples from the Brazilian context. We finish this research emphasizing the need for discussions and critical analysis about the democratization of technology and how this can provide a more equal and inclusive society.
\end{abstract}

\section{KEYWORDS}

Democratization of Technology, People with Disabilities, Social Inclusion, Critical Theory of Technology

\section{INTRODUCTION}

Technology, such as other systems and artifacts on our society act as instrumental support to reach objectives or impose wills, and with that, technology is an instrument of power in several segments as social, cultural, historical, political and economic. Thus, technology and decision related to its design and development became a social battlefield and a place of power disputes in our society (Feenberg, 2010; Neder, 2013).

Considering these topics, critical theorist Andrew Feenberg proposes the "Critical Theory of Technology". That theory is based on discussions of previous generations of "Critical Theory", with theorists such as Jürgen Habermas and Herbert Marcuse, among others, and approaches issues about values incorporated in technologies and how the democratization of its development process could result in a better society to people.

According to Feenberg (2013), modern society is organized surrounding technology, which indicates that changing the values embedded in technologies, and their producing processes could result in society shifts. This statement is also valid when we consider that society changes also perform technologies changes and all this occurs because technology and society are intrinsically related (Feenberg, 2010).

Feenberg's theory indicates that social groups excluded from technology development's decision process protests and do movements to express their dissatisfaction with the sociotechnical status. These movements indicate the possibility to expand the decisions about technologies to a more comprehensive scale, in which non-dominants groups concerns could also be considered in technology redesign (Feenberg, 2005). These actions may culminate in an increase in the social interests (Feenberg, 2010), and then the democratic transformation of technology could bring about economic, social, cultural, political, and historical changes.

With the discussion of social transformations through technological changes and as a means to strengthen his theoretical proposal, Feenberg presents examples of how non-dominant groups exert political pressure on society to have their demands recognized and, in some cases, reached. Examples include situations such as the criminalization of child labor in 19th century England, changes in technologies such as Minitel in France in the 1980s, and others. 
Our focus in this paper are people with disabilities movements regarding democratization of technology such as war veterans with physical disabilities protests for environments free of locomotion barriers in 1950-1960 in the United States; books written with people with disabilities concerning technologies development in 1998, presenting examples of how incorrect projects hinder people with disabilities' locomotion; among others. And we choose to use the "Critical Theory of Technology" since this theory act as lenses to tint or fade objects (Halverson, 2002; Rogers, 2012), and in this paper, such tinted objects are discussions on the relationship between society and technology. Furthermore, this theory already was used to analyze cases about that relationship, as Feenberg and other authors present, without focusing on people with disabilities examples.

Feenberg's theory approaches (1) the technologies creation and its relation with the social context; (2) the fact that social inequality in decisions on technology projects contribute to social injustice; and (3) examples to show how public involvement in technology design makes a difference in the sociopolitical context. Based on these points, Feenberg elaborates two primary theses (Cupani, 2017; Feenberg, 2002):

1. Technological development is overdetermined by both technical and social factors, so that it can branch in several directions, according to the values and power of the dominant groups;

2. Social groups adapt to technological development, and the adaptation process is reciprocal. Thus, technology changes according to its production context, at the same time it influences the production context.

From the points proposed by Feenberg's Critical Theory of Technology, it is possible to accomplish discussions about how non-dominant groups, particularly people with disabilities, can have their demands satisfied through social protests and mobilizations that culminate in changes in technology and more democratic practices related to technology. Thus, this paper aims to discuss Feenberg's theory regarding examples about the rights of people with disabilities movement and how their results or related actions can perform changes in technology and society. Our focus are examples of these movements regarding Brazilian contexts, particularly cases related to internet use and governmental regulations, though we present examples of other movements occurred in other countries. The instrument used in this paper to analyze these examples, are the two hermeneutic dimensions proposed in Feenberg's theory.

This paper is organized as follows: the second section presents important details of Feenberg's Critical Theory of Technology; the third section presents our discussions on how people with disabilities movements can be articulated with Feenberg's theory and examples of these connections; finally, the last section presents our final remarks and further research appointments.

\section{FEENBERG'S CRITICAL THEORY OF TECHNOLOGY}

In addition to critically extending discussions held by the early generations of critical theorists such as Max Horkheimer, Theodor Adorno, Walter Benjamin, Jürgen Habermas, and Herbert Marcuse, Feenberg bases his theory on the critical discussion of various theories that advocate technology dependence in modern society; theories that use as argument forms of technological determinism. From this critical analysis, Feenberg elaborates his non-deterministic theory of modern society, the Critical Theory of Technology, which emphasizes contextual aspects of technology that are ignored by the dominant view (Feenberg, 2010).

As a starting point to discussing the possibility of democratization of technology, Feenberg (2010) presents his reason to refute the fundamental argument against industrial democracy ${ }^{1}$, which is based on Max Weber's theory of rationalization, a theory followed by intellectuals such as Heidegger and McLuhan. The argument of this theory indicates that rationalization plays a fundamental role in the increasing control of social life in order to imposes an authoritarian social hierarchical structure, in a context of apparent autonomy of technology. Feenberg argues that there must be other alternatives to rationalizing society so that it is more democratic and holds other values such as liberty and individuality. In addition, he argues that the examples used against industrial democracy are identified with specific technologies created in the last century in the West, so that can not be related to an entire universal dimension of modernity (Feenberg, 2010).

From this discussion about the possibility of a new rationality of society, more democratic and participative, Feenberg analyzes three theories of technology (technological determinism, social constructivism, and

\footnotetext{
${ }^{1}$ Feenberg's reference to Karl Marx studies, about the democratization of the work domain as well as political domain.
} 
indeterminism) to articulate his theoretical proposal. He points out the need to change the definition of technology, so that it "can no longer be considered as a collection of devices nor, more generally, as the sum of rational means" (Feenberg, 2010, p. 13). With this new definition of technology's concept, he argues that technology must be understood as a social object that is subjected to interpretation as any cultural artifact so that it is not possible to ignore the connections between technology and society (Feenberg, 2010).

Feenberg's interpretation of the technical object admits two hermeneutic dimensions: the social meaning and the cultural horizon. Social meaning is related to functional logic of technology, which may have a conflict of use interpretations, or have different definitions according to the characteristics of its components that contribute to attribute meaning to objects. Thus, "differences in the way social groups interpret and use technical objects are not merely extrinsic but make a difference in the nature of the objects themselves" (Feenberg, 2010, p. 15). This point is very important in the critical theory of technology by refuting arguments of technological determinism, which indicates that social groups need to adapt to technologies, particularly by believing that they are universal structures, argument refuted by Feenberg.

The cultural horizon, the second hermeneutic dimension of the technical object, is related to the fundamental forms of social hegemony. The conception adopted to form the cultural horizon refers to the configuration of the social power of a society, which has its base and strength in culture (Feenberg, 2010). This dimension of the technical object contributes in Feenberg's discussion to expresses the possibility to create different technologies, with different values, from the moment they are based on new rationality of society; such as an inclusive and democratic society.

With the two hermeneutic dimensions of the technical object, Feenberg elaborates the argument that the social and technical aspects of technology are inextricably involved in the same object (Feenberg, 2010). By analyzing technology in this way, it is possible to understand its power in society, since technologies are selected and designed based on the interests of specific groups that, through cultural and political power, define the cultural horizon under which technology will act. From the moment a technology is introduced into society, it begins to act as a material validation of the cultural horizon and consequently of the values that it incorporates (Feenberg, 2010). Moreover, these dimensions indicate the ability of social groups to adapt to technological development, at the same time that technologies are adapted to social changes, meaning a process of reciprocal modification (Cupani, 2017; Feenberg, 2010).

Based on the points presented to substantiate the Critical Theory of Technology, Feenberg argues that it is the perception of these possibilities of changes and deformations in the technologies that foment political movements towards the transformation of technology and society (Cupani, 2017). Feenberg's argument is based on the fact that the dominant groups of the technical code do not have enough strength to silence or erase the groups and communities that mobilize themselves to make their opinions and desires known. Examples of non-dominant groups movements and actions regarding technology are:

- Protests against the implementation of nuclear power plants next to urban areas (Feenberg, 2010);

- E-mail's changes over the years; which was introduced by skilled users and was not part of the designers' plans to be used as a worldwide communication tool (Feenberg, 2006);

- Child labor criminalization in the 19th century in England (Feenberg, 2010);

- Minitel transformation into a communication and entertainment tool (Feenberg, 2010);

- The case of the United States steamboat boilers in 1852, which represented the first technology that the US government subjected to regulation (Feenberg, 2010);

- AIDS patients' dispute in the 1980s who required participate in the new drugs tests to treat that disease (Feenberg, 1995; 2010);

- The movement of people with physical disabilities in the 1970s in the United States who protested against the adoption of technologies (machines, instruments, roads, sidewalks, transportation facilities, among others) that did not contemplate their disabilities, constraining their autonomy and independence (Cupani, 2017).

The Critical Theory of Technology discussions are based on examples such as those presented before to indicate a tendency for people participation in decisions of technology design and development. That kind of openness can expand into areas in which only experts and technicians have the power to decide about the developed technologies (Feenberg, 2006). Feenberg's perspective is that this tendency will reach larger spheres, in which population involvement in decisions about the technical structure influences the ways of life of society so that it would result in a better world (Feenberg, 2006). However, it is important to note that the society's shift toward the democratization of technology is replete of tensions and power disputes. That is the reason to 
Feenberg's argument on the need to talk about more modestly of democratic interventions into technology, not a utopian democracy of techniques (Feenberg, 2006).

Finally, it is important to emphasize that the Critical Theory of Technology has other elements and particularities not approached in this article. However, we expect the content discussed in this paper presents sufficient points to consider the use of the Feenberg's theory in contexts and examples different from those shown by the theoretician and from this to foment discussions about the technology development and its democratization.

\section{CRITICAL THEORY OF TECHNOLOGY AND SOCIAL INCLUSION OF PEOPLE WITH DISABILITIES}

Feenberg's Critical Theory of Technology and the examples and questions presented previously contribute to the study of other political and social movements related to technologies. One of these is the rights of people with disabilities movement.

Events related to the rights of people with disabilities have taken place over the years in several regions of the world. Examples of these movements are:

- The case of war veterans with physical disabilities who protested for environments without locomotion barriers in the decade of 1950-1960 in the United States, that resulted in the first American norms of accessibility in buildings (Sassaki, 2011);

- The discussion on the inadequacy of the medical model of disability in South Africa, in the 1980s, culminating in the elaboration of the motto "Nothing about us, without us" and in the future amendment of United Nations (UN) documents on the medical model of disability (Sassaki, 2011);

- The publication of books with people with disabilities' participation in the development of technologies in 1998, such as Nothing about us without us: developing innovative technologies for, by and with disabled persons (David Werner, 1998), as a means of presenting examples of how incorrect projects are detrimental to the lives of people with disabilities (Sassaki, 2011);

- Madrid Declaration presentation in 2002, which explicitly indicated the need to adequately represent people with disabilities in media (Sassaki, 2011);

- The creation of one of the most important documents for the rights of people with disabilities, the Convention on the Rights of Persons with Disabilities (CRPD), presented in 2006 with the signature of 158 countries in its opening. It describes and codifies the rights of people with disabilities and outlines how they might be achieved (Ladner, 2014).

Based on global rights of people with disabilities movement, we focused on some examples of the Brazilian context as our discussion context in the following sections.

\subsection{The Brazilian Context}

Among the results of the rights of people with disabilities movement is the Brazilian Inclusion Law (LBI), considered as one that instigates clearer and more objective technological changes in Brazil. The law has been in conception for 15 years, and in addition to being compatible with the terms presented in the CRPD, explores issues such as access to information and communication technology (ICT), which were previously not mandatory or were not specified in detail (Brasil, 2015; Gabrilli, 2015).

While Article 21 of the CRPD declares that Nations that have signed the convention should "encouraging the mass media, including providers of information through the Internet, to make their services accessible to persons with disabilities" (United Nations, 2019), LBI, in its article 63, makes this action mandatory. Thus

accessibility is obligatory on websites maintained by companies with headquarters or commercial representation in the country or by government agencies for people with disabilities use, ensuring access to the available information, in accordance with best practices and accessibility guidelines adopted internationally.

This and the other modifications proposed in the LBI, related to CRPD or other regulations, stimulate changes in the technologies of our society. In the specific case of LBI's article 63, the changes can already be perceived in official documents to facilitate a standardized web accessibility implementation, such as "Accessibility Model in Electronic Government" (eMAG) - a guideline to development and adaptations of the government digital content (Brasil, 2014). Websites of public institutions, as indicated in the law, are also in the process of being updated for implementing accessibility features. Some cities such as São Paulo established 
a partnership with "Permanent Commission for Accessibility"2 to organize a digital accessibility certificate to identify websites that comply with guidelines and recommendations such as eMAG and WCAG (Junior, 2018; Prefeitura de São Paulo, 2018). The movement "Web for all", a response to LBI, proposes a meeting point for institutions, developers and people with disabilities in order to mobilize society for debate about digital accessibility, and to help to transform the Brazilian web into an inclusive environment for all (WPT, 2019).

The cases of explosive boilers in the United States in 1852 and the criminalization of child labor in 19th century in England (Feenberg, 2010) are references to analyze the relationship between the discussions proposed by Feenberg and the movement of people with disabilities, such as the LBI and the technical changes triggered in websites accessibility. In this case, we understand that changes were made in society through people with disabilities protests and their participation in circumstances such as LBI formulation. Following we highlight some examples of these changes:

- Changes in public and private websites for implementation of accessibility features, resulting in technological and cultural changes;

- Architectural, cultural, or political changes that are influenced by changes in technologies such as the creation of access ramps for people with physical disabilities or mobility constraints;

- Ensuring the inclusion of people with disabilities at the university, culminating in structural, cultural, and political changes in universities, that need to adapt their environments and services to attend this public.

Thus, technological changes promoted by the LBI, which was created in response to protests by non-dominant groups, reinforce Feenberg's arguments by indicating the existence of technical and social aspects in the technologies, and how they can be adapted by society. Furthermore, the LBI changes can provide web accessibility to $57 \%$ of Brazilian with disabilities, who access the Internet daily (NIC.br, 2017).

\subsection{LBI and the Two Hermeneutic Dimensions of the Critical Theory of Technology}

Specifically, in the case of web accessibility motivated by LBI, it is possible to consider that the social meanings, the first hermeneutic dimension of Feenberg's theory, of accessible websites can be:

1. Created by people with disabilities who have access to information, citizenship, culture, and entertainment websites;

2. Interpreted by people without disabilities who can understand the importance of implementing accessibility features, even if they do not need to use them;

3. Interpreted by professionals who create or apply accessibility features on websites: (a) they have the opportunity to understand their role as citizens and seek ways for more people to have access to information; (b) according to the Brazilian Internet Steering Committee (2015), professionals can understand that action as an opportunity to bring new consumers for their products.

Regarding the cultural horizon, second hermeneutic dimension of Critical Theory of Technology, it is important to highlight the involvement of several groups in the LBI definition (politicians, people with disabilities, general society members, among others); and other groups work in the implementation of accessibility features of websites (programmers, designers, advertisers, journalists, testers, among others) (Gabrilli, 2015). With these groups' involvement and despite tensions and disputes, their main goal and values were aligned during the discussion of LBI concepts or to the creation of accessibility resources, which in this case are values and objectives related to the social inclusion of people with disabilities through ICTs. In this sense, the change in rationality discussed by Feenberg is shown to be possible, reinforcing elements pointed out in the Critical Theory of Technology by the theoretician. In LBI's case, the rationality was the social inclusion of people with disabilities, and these values are reflected on LBI as well.

Another example of web accessibility, but not directly related to LBI, is the use of hashtags \#ToBlindSee, \#Accessibility, \#TimelineAccessible, among others, as a mechanism to provide alternative text for images or events description in social networks like Facebook and Twitter and thus complement the caption of a post, particularly postings whose subject matter refers to images (Pagani, 2018). The use of these hashtags is a way that people in Brazil have found to include a feature that these social networks did not provide in their original project (Pagani, 2018).

\footnotetext{
${ }^{2}$ A public organization of São Paulo City that works combined with the Secretary of the Person with Disabilities of São Paulo (SMPED) and is composed of representatives of several public agencies, and civil society.
} 
This type of action is remarkable for people with disabilities, who are also social networks users, to have access to information and content of several sources, such as entertainment, science, education, journalistic communication, among others (Souza; Siqueira, 2017). In addition, these actions indicate the recognition of people with disabilities as an intended audience of content, web resources and technologies, since these actions introduce ways for people with disabilities to access, understand and interact with online content (Souza; Siqueira, 2017).

It is important to emphasize that the actions of several groups and companies by using the hashtags could result in a technological change in social networks. We understand this because Facebook and Twitter did not have options to include image alternative text until 2016 (Anderson, 2016; Todd, 2016), and the use of hashtags was proposed in 2012 in Brazil (Braille, 2012). In this way, we understand that social networking technology changed, as well as in the e-mail example and Minitel (Feenberg, 2000), what reinforces Feenberg's argument about technology adaptations initiated by society; and the use of hashtags reinforces the society's change as well as a technological change. Nevertheless, even whether people reassemble the technology to accomplish their needs, we cannot assure the adjustments on those social networks is exclusively related to the the hashtags case, for the reasons that this affirmation demand more investigations on the process and causes for technology modification.

Related to one of the two hermeneutic dimensions elaborated by Feenberg, we consider that the social meaning of the hashtags use can be interpreted by the rights of people with disabilities movement as a way of denouncing the technological problems and a way to present the agenda of real and important problems in society, especially related to information access, with other groups (web developers, public and private institutions, among others) mobilized to attempt to solve the problem (Souza; Siqueira, 2017). People with disabilities who use social networks are also benefited by the hashtags use, for the reason that they can be connected with their friends and family and have a channel for social interaction, through social networks, as well as access to information (Souza; Siqueira, 2017).

Related to the cultural horizon, Feenberg's second hermeneutic dimension, it is possible to highlight two power configurations at different moments. One configuration in the use of the hashtag and another in the technology adaptation of social networks.

The groups involved in the use of hashtags in social networks has as its members people from non-dominant power groups, who wish to have their demands listened and satisfied, which characterizes the cultural horizon with the values of social inclusion of people disabilities that are incorporated into technologies through the use of hashtags. This activity leads to technological change that is controlled by, as Feenberg (2010) calls, the "masters of technical systems" (corporate and military leaders, and professional associations of groups such as physicians and engineers), which in response to the use of hashtags, modifies the social networks technologies and incorporates in it values of social inclusion of people with disabilities. In this way, the actions performed by the people using the hashtags induced adaptations in the technology and in the values incorporated in it. This illustrates the inextricability of technical and social aspects of technology, as Feenberg affirms, and also exposes the possibility that by democratizing the design of technologies, they incorporate more human values and influence the accomplishment of a more inclusive society.

Although Feenberg's two hermeneutic dimensions can be used as an instrument to analyze social movements that demand technological changes, it is important to emphasize that there are relevant points in such analyzes, which are not considered in such analysis. An example of this may be associated with the technical object development that, although it may be related to the two hermeneutic dimensions, is not addressed particularly by any of them. Thus, in addition to considering the way the object is interpreted in society (the first hermeneutic dimension) and the social configuration that incorporates its values in the structure of the object (second hermeneutic dimension); can be relevant to consider the development process of that object, the people involved and the decisions of this process that resulted in the artifact used in society. In considering this other aspect of the technical object, it may be possible to understand in greater depth unfoldings of it in society, as well as the possibilities of modifications made later. Furthermore, by investigating the technology development process, through Feenberg's hermeneutic dimensions, we can also contribute to thinking about how the inclusion of people with disabilities can take place in projects that are defined as inclusive from the beginning. 


\section{CONCLUDING REMARKS}

Considered a part of society, technology can be modified to propitiate changes in society, since, according to Cupani (2017), this constitutes the "material structure" of modern society. Based on this relationship between society and technology, Feenberg elaborates his Critical Theory of Technology that, as presented throughout this paper, proposes discussions about the power exerted through technology in modern society and how it causes changes in the society that consumes and produces it, at the same time that it is changed by the society. In this sense, Feenberg declares that technology incorporates values and interests from the dominant classes that determine how technologies are so that these values are engraved in the technologies' designs and procedures (Cupani, 2017). In this way, technology cannot be understood as a neutral instrument in society, but rather an artifact involving disputes of power and social control (Cupani, 2017; Feenberg, 2010).

In order to achieve social and technological changes, Feenberg understands that it is necessary the processes of technologies development be more democratic, so non-dominant social groups have their demands and values considered and inserted in the technologies design. In this way, both society and technologies can reach more coherent values to the people needs and well-being.

Based on Feenberg's theory propositions, we were able to analyze and discuss how social groups can mobilize themselves to bring changes in society through technology or changes in technology that culminate in social changes. Examples of this are presented by Feenberg to verify his theoretical proposal, as well as to refute theories that advocate for technological determinism. In this sense, the objective of this paper was to discuss how some actions related to the rights of people with disabilities movement in Brazil opened space for changes in technology and society.

The examples presented in this paper on some questions about web accessibility to meet the needs and demands of people with disabilities indicate how it is possible to base the concepts presented in the Critical Theory of Technology for analytical evaluations or actions regarding accessibility and social inclusion aspects related to technology and its development. In this sense, these examples contribute to highlight the means to produce and redesign technologies with more inclusive values so that people with and without disabilities have access to the same contents and opportunities, providing a more democratic and inclusive society.

It is important to emphasize that the examples presented and discussed in this paper are still an initial step towards the social inclusion of people with disabilities and the democratization of technology and that can not be limited to what has been achieved, even if they exemplify courageous actions in our society. Thus, there is an opportunity to rely on these examples and on the critical theory of technology to discuss other mechanisms and schemes used by the dominant groups to maintain their power, and through these examples and theories, to discuss social and technological changes in favor of more democratic, responsible and inclusive society.

Finally, it is important to recognize that the technical object may present other dimensions or points to be discussed that are not addressed by Feenberg's hermeneutic dimensions. In this way, future analyzes might consider the theory's gaps and present other perspectives of the democratization of the technology.

\section{ACKNOWLEDGEMENT}

To Fundação Araucária, CAPES and PPGTE. This study was financed by the Coordenação de Aperfeiçoamento de Pessoal de Nível Superior - Brasil (CAPES) - Finance Code 001.

\section{REFERENCES}

Anderson, S., 2016. Social media now using alternative text for images. Thomas Pocklington Trust, accessed 25 February 2019, <https://www.pocklington-trust.org.uk/social-media-now-using-alternative-text-images/>

Braille, P., 2012. Pra Cego Ver: uma proposta de descrição de imagens para o Facebook. Blog da Audiodescrição, accessed 25 February 2019, <http://www.blogdaaudiodescricao.com.br/2012/06/pra-cego-ver-uma-propostadedescricao.html>

Brasil, 2014. eMAG: Modelo de Acessibilidade em Governo Eletrônico. Ministério do Planejamento, Orçamento e Gestão - Secretaria de Logística e Tecnologia da Informação, accessed 25 February 2019 < http://emag.governoeletronico.gov.br/> 
Brasil, 2015. Lei Brasileira de Inclusão da Pessoa com Deficiência - Lei no 13.146, de 6 de julho de 2015. Presidência da República - Casa Civil - Subchefia para Assuntos Jurídicos, accessed 25 February 2019 <http://www.planalto.gov.br/ccivil_03/_ato2015-2018/2015/lei/113146.htm>

Brazilian Internet Steering Committee - CGI.br, 2015. Cartilha Acessibilidade na Web - Fascículo II. Ebook, accessed 25 February 2019, <http://www.w3c.br/pub/Materiais/PublicacoesW3C/cartilha-w3cbr-acessibilidade-web-fasciculoII.pdf>

Cupani, A., 2017. Filosofia da tecnologia: um convite. Florianópolis: Editora da UFSC, 3. ed.

Feenberg, A., 1995. Alternative modernity: The technical turn in philosophy and social theory. Univ of California Press.

Feenberg, A., 2000. From essentialism to constructivism: Philosophy of technology at the crossroads. In Technology and the good life?, pp. 294-315, University of Chicago press.

Feenberg, A., 2002. Transforming technology: A critical theory revisited. Oxford University Press.

Feenberg, A., 2005. Critical Theory of Technology: An Overview. Tailoring Biotechnologies, Vol. 1, Issue I, pp. 47-64.

Feenberg, A., 2006. What is philosophy of technology?. In Defining technological literacy, pp. 5-16. Palgrave Macmillan, New York.

Feenberg, A., 2010. Between reason and experience: Essays in technology and modernity. MIT Press.

Gabrilli, M., 2015. LBI- Lei Brasileira de Inclusão. Accessed 26 February 2019, < http://maragabrilli.com.br/wpcontent/uploads/2016/03/Guia-sobre-a-LBI-digital.pdf>.

Halverson, C. A., 2002. Activity theory and distributed cognition: Or what does CSCW need to DO with theories? Computer Supported Cooperative Work (CSCW), 11(1-2), 243-267.

Junior, I., 2018. Acessibilidade WEB e o desafio do Selo Acessibilidade Digital. Mãos em movimento Libras e Educação Especial, accessed 25 February 2019 <http://www.maosemmovimento.com.br/selo-de-acessibilidade-digital/>

Ladner, R., 2014. The impact of the united nations convention on the rights of persons with disabilities. Communications of the ACM, v. 57, n. 3, pp. 30-32, mar. 2014. ACM, New York, NY, USA.

Neder, R. T., 2013. O que (nos) quer dizer a teoria crítica da tecnologia? In A teoria crítica de Andrew Feenberg: racionalização democrática, poder e tecnologia. Brasília: Observatório do Movimento pela Tecnologia Social na América Latina. pp. 7-23.

NIC.br, 2017. Web para Todos quer acabar com as barreiras de navegação na Internet no Brasil. Accessed 25 February 2019, <https://www.nic.br/noticia/releases/web-para-todos-quer-acabar-com-as-barreiras-de-navegacao-na-internetno-brasil/>

Pagani, T., 2018. Trabalhando com texto alternativo de imagens em redes sociais: Saiba com inserir texto ALT no Facebook e Twitter. Ux.blog, accessed 25 February 2019, <https://uxdesign.blog.br/trabalhandocom-texto-alternativode-imagens-em-redes-sociais-a22fa214ee6>

Prefeitura de São Paulo, 2018. Selo de Acessibilidade Digital. Accessed 25 February 2019, <https://www.prefeitura.sp.gov.br/cidade/secretarias/pessoa_com_deficiencia/selo_de_acessibilidade_digital/>

Rogers, Y., 2012. HCI theory: classical, modern, and contemporary. Synthesis lectures on human-centered informatics, 5(2), 1-129.

Sassaki, R. K., 2011. Nada sobre nós, sem nós: Da integração à inclusão. Bengala Legal, accessed 25 February 2019 <http://www.bengalalegal.com/nada-sobre-nos>

Souza, J. B.; Siqueira, J. M., 2017. Redes sociais: tecnologias assistivas para a inclusão e a cidadania. Revista Periferia: Educação, Cultura e Comuniação, v. 9, n. 1, pp. 112-129.

Todd., 2016. Accessible images for everyone. Blog Twitter, accessed 25 February 2019, <https://blog.twitter.com/official/en_us/a/2016/accessible-images-for-everyone.html>

United Nations, 2019. Article 21 - Freedom of expression and opinion, and access to information. United Nations Disability: Department of Economic and Social Affairs, accessed 25 February 2019, <https://www.un.org/development/desa/disabilities/convention-on-the-rights-of-persons-with-disabilities/article-21freedom-of-expression-and-opinion-and-access-to-information.html >

WPT, 2019. Web para todos. Accessed 25 February 2019, <http://mwpt.com.br/> 